\title{
Primeira ocorrência de Puccinia nakanishikii em capim limão no Paraná
}

\author{
José Junior Severino ${ }^{1}$, Cláudia Regina Dias-Arieira ${ }^{1}$, Dauri José Tessmann², Vinícius Hícaro Frederico Abe ${ }^{1}$
}

${ }^{1}$ Universidade Estadual de Maringá, Departamento de Ciências Agronômicas, Estrada da Paca s/n, 87507-190, Umuarama, PR. ${ }^{2}$ Universidade Estadual de Maringá, Departamento de Agronomia, 87020-900, Maringá - PR.

Autor para correspondência: Cláudia Regina Dias-Arieira (crdarieira@uem.br) Data de chegada: 08/10/2013. Aceito para publicação em: 05/12/2013.

O capim-limão (Cymbopogon citratus (DC.) Stapf), também conhecido como capim santo ou capim cidreira, é uma espécie da família Poaceae, nativa de regiões tropicais da Ásia, que se desenvolve bem em todas as regiões do Brasil. É utilizada para fins medicinais e aplicação nas indústrias farmacêuticas, alimentícias e perfumaria. Suas folhas apresentam vários óleos essenciais, sendo o citral o principal componente.

A partir do mês de abril de 2013, constatou-se a presença de lesões foliares ferruginosas escuras, na forma de pústulas alongadas, na parte abaxial das folhas de capim limão, no Horto de Plantas Medicinais da Universidade Estadual de Maringá, Campus Regional de Umuarama. Amostras destas plantas foram coletadas e encaminhadas ao Laboratório de Fitopatologia, onde foram observadas sob estereomicroscópio. Em seguida, realizaram-se cortes transversais e coleta de esporos para confecção de lâminas temporárias, para observação das estruturas sob microscópio óptico.

Nas folhas, verificou-se urediniossoros na face abaxial, em manchas alongadas e necróticas (Figura 1A). Sob microscópio, observou-se a presença de teliósporos produzidos nos urediniossoros, em sua maioria elipsides, medindo de 32,55 a $37,82 \mu \mathrm{m}$ de comprimento e 21,08 a $26,35 \mu \mathrm{m}$ de largura, bicelulares, marromcastanhos, lisos, com paredes engrossadas até $5 \mu \mathrm{m}$ no ápice, pedicelos marrons, com paredes finas (Figura 1B); urediniósporos obovoides com 28,05 a 33,79 $\mu \mathrm{m}$ de comprimento e 21,08 a 25,00 $\mu \mathrm{m}$ de largura, marrom canela-escuros abaixo e marrom acastanhados acima, equinulados, com quatro a cinco poros germinativos equatoriais (Figura 1C); paráfises capitadas ou clavada-capitadas, paredes finas abaixo e engrossadas acima, 6,20 a 6,82 $\mu \mathrm{m}$ espessas no ápice (Figura 1D), de amarelo-pálidas a amarelo-ouro.

Estas características estão de acordo com aquelas observadas por Melo et al. (Tropical Plant Pathology, 35:129-130, 2010) para Puccinia nakanishikii Dietel (Uredinales) em capim limão no estado do Rio de Janeiro. Além desta, a espécie Puccinia cymbopogonis Massee foi anteriormente assinalada parasitando capim limão no estado de São Paulo (Russomano et al., Summa Phytopathologica, 34:81, 2008) e no Paraná (Vida et al., Summa Phytopathologica, 32:89-91, 2006). Uma terceira espécie, Puccinia purpurea Cke., foi encontrada parasitando C. citratus na Colômbia (Pardo-Cardona, Fitopatologia Colombiana, 23:43-44, 1999).

Este é o primeiro relato da espécie P. nakanishikii no estado do Paraná e o segundo no Brasil. Amostra do material encontrase depositada no Laboratório de Fitopatologia da Universidade Estadual de Maringá, Campus Regional de Umuarama, sob o código F-Pc-01-UMU.
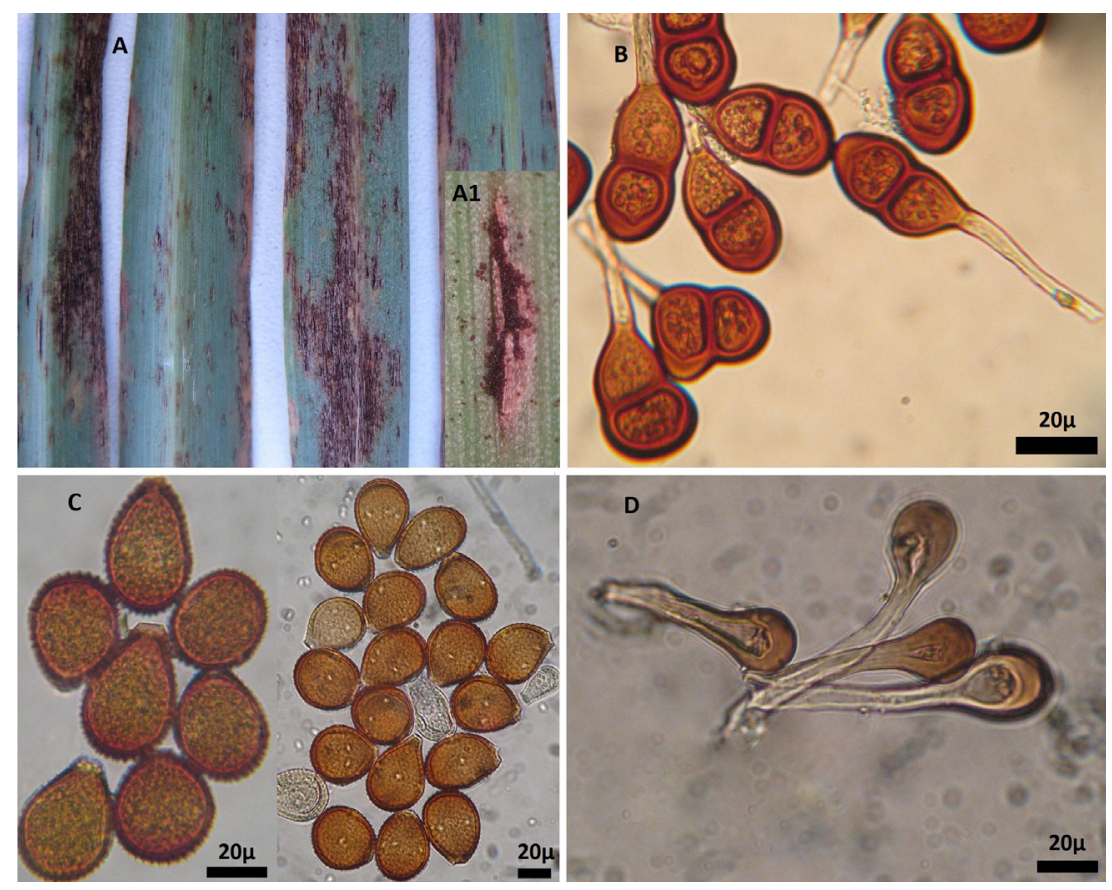

Figura 1. Puccinia nakanishikii. Sintomas da ferrugem em capim limão (A). Teliósporos (B). Urediniósporos (C). Paráfises capitadas (D). 